\title{
ON THE OPERATOR ACZÉL INEQUALITY AND ITS REVERSE
}

\author{
SHIGERU FURUICHI*, MOHAMMAD REZA JABBARZADEH \\ AND VENUS KALEIBARY
}

Abstract. In this paper, we present some operator and eigenvalue inequalities involving operator monotone, doubly concave and doubly convex functions. These inequalities provide some variants of the operator Aczél inequality and its reverse via the generalized Kantorovich constant.

Mathematics subject classification (2010): 47A63, 47A64, 15A60, $26 \mathrm{D} 15$.

Keywords and phrases: Aczél inequality, operator monotone function, operator convex function, geometrically convex function, Kantorovich constant.

\section{REFERENCES}

[1] J. ACZÉL, Some general methods in the theory of functional equations in one variable. New applications of functional equations, Uspehi Mat. Nauk (N. S.) 11 (1956), 3-68 (Russian).

[2] M. BAKHERAD, Refinements of a reversed AM-GM operator inequality, Linear Multilinear Algebra. 64 (9) (2016), 1687-1695.

[3] R. Bhatia, Matrix Analysis, Grad. Texts in Math., vol. 169, Springer-Verlag, 1997.

[4] J.-C. BOURIN AND F. HIAI, Jensen and Minkowski inequalities for operator means and anti-norms, Linear Algeb Appl. 456 (2014), 22-53.

[5] J. C. Bourin, E. Y. LeE, M. Fuji AND Y. SEO, A matrix reverse Hölder inequality, Linear Algebra Appl. 431 (2009), 2154-2159.

[6] S.S. DRAGOMIR, A generalization of Aczél's inequality in inner product spaces, Acta Math. Hungar. 65 (1994), 141-148.

[7] T. Furuta, J. Mićić, J. E. PeČARIĆ And Y. SEO, Mond-Pečarić method in operator inequalities, Monographs in Inequalities 1, Element, Zagreb, 2005.

[8] M. B. GHAEMI AND V. KALEIBARY, Some inequalities involving operator monotone functions and operator means, Math. Inequal. Appl. 19 (2016), 757-764.

[9] M. B. GHAEMI AND V. KAlEIBARY, Eigenvalue inequalities related to the Ando-Hiai inequality, Math. Inequal. Appl. 20 (2017), 217-223.

[10] V. Kaleibary and S. Furuichi, Reverses of operator Aczél inequality, C. R. Math. Acad. Sci. Paris. 356 (5) (2018), 475-481.

[11] M. S. Moslehian, Operator Aczél inequality, Linear Algebra Appl. 434 (2011), 1981-1987.

[12] T. Popoviciu, On an inequality, Gaz. Mat. Fiz. Ser. A. 11 (1959), 451-461 (in Romanian).

[13] J. TIAN AND W.-L. WANG, Generalizations of refined Hölder's inequalities and their applications, Mathematical Problems in Engineering, Vol. 2014 (2014), Article ID 581962, 11 pages.

[14] J. ZHAO AND J. WU, Operator inequalities involving improved Young and its reverse inequalities, J. Math. Anal. Appl. 421 (2) (2015), 1779-1789. 